RESEARCH ARTICLE / ARAŞTIRMA YAZISI

\title{
Kadınlarda Çocuk Sayısı ile Pozitif Negatif Duygular Arasındaki İlişkinin Incelenmesi
}

Hüseyin ÜNÜBOL ${ }^{1}$, Meltem SUNAR ${ }^{2}$, Gökben Hızı SAYAR ${ }^{3}$

Özet:Bu araştırmanın amacı kadınlarda pozitif negatif duygu durumlarının sahip oldukları çocuk sayısına bağlı olarak ne oranda etkilendiğini belirleyebilmektir. Çalışmada verilerin toplanması için Pozitif ve Negatif Duygulanım Ölçeği (PNDO) kullanılmıştır. Araştırma 26 NUTS3 bölgesindeki katılımcılar üzerinden planlanmıştır. Araştırmanın örneklemi dokuz demografik bölgeyi kapsayan toplam 12189 kadın katılımcıdan oluşmaktadır. Araştırmada yapılan ANOVA analizi sonuçlarında çocuk sahibi olmayan kadınların pozitif duygu durumlarının daha düşük olduğu tespit edilmiştir. Ayrıca çocuk sahibi olmayan kadınların negatif duyguları çocuk sahibi olan kadınlara göre daha yüksek olduğu tespit edilmiştir.

Anahtar Sözcükler: Pozitif duygu durumu, Negatif duygu durumu, İyi oluş, Pozitif ve negatif duygulanım ölçeği, Kadın să̆lı̆̆ı.

ToAnalyzeTheRelationshipBetweenNumber of ChildrenandPositiveNegativeEmotions in Women

\begin{abstract}
The aim of this study is to determine the extent to which positive and negative emotions are affected by the number of children women have. In the study, the Positive and Negative Affect Scale (PNDO) have used to collect data. The study was planned on the participants in 26 NUTS3 regions. The sample of the study consisted of 12189 female participants covering nine demographic regions. According to the results of ANOVA analysis, it was found that women with no children had lower positive emotions. In addition, women without children had higher negative emotions than women with children negative emotions.
\end{abstract}

Keywords: Positive emotion status, Negative emotion status, Well-being, Positive and negative affect scale, Women's health.

${ }^{1}$ Dr., Üsküdar Üniversitesi, İnsan ve Toplum Bilimleri Fakültesi

${ }^{2}$ Uzm., Üsküdar Üniversitesi, Psikoloji Bölümü, Doktora Öğrencisi

${ }^{3}$ Doç. Dr. Üsküdar Üniversitesi, İnsan ve Toplum Bilimleri Fakültesi

Address of correspondence/Yazş̧ma adresi: Uzm. Meltem Sunar, Üsküdar Üniversitesi, Psikoloji Bölümü, Doktora Öğrencisi, meltem.senkan@hotmail.com

Date of Received/Geliş Tarihi: 22.11.2019, Date of Revision/Düzeltme Tarihi: 23.01.2020, Date of Acceptance/Kabul Tarihi: 15.03.2020

Citing/ Referans Gösterimi: Ünübol, H., Sunar, M., Sayar, G.H. (2020). Kadınlarda Çocuk Sayısı ile Pozitif Negatif Duygular Arasındaki İlişkinin İncelenmesi. Klbrıs Türk Psikiyatri ve Psikoloji Dergisi, 2(1): 314ldoi:10.35365/ctjpp.20.2.5 


\section{Giriş}

Birleşmiş Milletlerin araştırmalarına göre son elli yıllık sürede kadınlarda doğum sayısı yarı yarıya azalmıştır. İlgili raporda gelişmişlik düzeyi yüksek olan ülkelerde doğurganlık oranı 1,7'ye düșmüștür. 1960'lı y1llarda bu sayının iki katı olduğu ifade edilen raporda kadınların istediğinden fazla çocuğa sahip olduklarına dair yoruma da yer verilmistir (UNFPA, 2018). Türkiye'de de aynı durum görülmektedir. Son beş yılın rakamları incelendiğinde 2014'te 2,19, 2015'te 2,15, 2016'da 2,11, 2017'de 2,07 ve 2018'de bu rakam 1,99 düsmüstür (TÜİK, 2018). Türkiye'de kadınların çocuk sahibi olmaya bakış açılarındaki değişimin toplumsal-kültürel, aile ve ekonomik nedenleri olduğu gibi doğurganlık nedeniyle ortaya çıkan sağlı sorunları bulunmaktadır (Aysan, 2015). Türkiye'de doğum sayısının azalmasının en önemli nedeni eğitim seviyesindeki artış ve istihdama katılan kadınların iki çocuktan fazla çocuğa sahip olmama düşüncesi yer almaktadır (Attar, 2015).

İsteğe dayalı veya istem dışı olan her gebeliğin bilinçli ve bilinçdışı sebepleri bulunmaktadır. Bu sebepler, sevmek ve sevilmek ihtiyacı, yetiștirme arzusu, kadınlığ kanıtlama ve bazı durumlarda kayıların telafi edilmesi olarak meydana gelmektedir (Kuğu ve Akyüz, 2001). Çocuk sahibi olan kadınların ruhsal sağlığı çocuk bakımı kalitesi, anne ve çocuk arasındaki bağın kalitesi ve çocuğun gelecek hayatında psikopatolojik sorunlar yaşaması açısından önem taşımaktadır (Sarıkaya, 2019). Kadın-anne sağlığı konusu, günümüzde ülkelere ait gelişmişlik seviyelerinin karşılaştırılmasında kullanılan göstergelerin başında gelmekte ve ilgili alana yapılan her müdahalenin somut bir çıktısı olmaktadır ve bu noktada kadının iyi oluş hali çocuk sağlığı ve aile sağlığını doğrudan etkilemektedir (Kilınç ve ark., 2012). Bu nedenle kadınların psikolojik iyi oluşu ve ruh sağlığı önem taşımaktadır.

Aile içerisindeki çiftler arası, ebeveyn ve çocuk arası ilişki ve çocuk gelișimi gibi konular son yıllarda ilgi ceken kavramlar arasında yer almaktadır (Parlar ve Eroğlu, 2018). Bir anne olarak kadınlar çocuklarını etkilediği gibi onlardan da etkilenmektedir (Sirin, 2000). Genç annelerde ve daha çok çocuğa sahip kadınlarda depresif belirtiler daha sik görülebilmektedir (Kayahan ve ark., 2003). Ancak kadınlarda evli ve çocuk sahibi olanlarınpsikolojik sağlığında bekarlara göre olumlu yönde artış olduğunu gösteren çalışmalar bulunmaktadır (Uludağl1, 2017). Ebeveyn olmanın kadınların yaşamına etkisi konusundaki araștırmalar farklılık göstermektedir.

İyi oluş hali kavramı incelendiğinde yeterlilik, temel ihtiyaçları karşılayabilme, özerklik ve ilişki kurabilme becerileri olarak tanımlanmaktadır (Ryan\&Deci, 2001). Bir başka tanıma göre iyi oluş hali, yaşama dair amaçların ve yaşamanın anlamını saptayabilme becerisidir (McGregor ve Little, 1998). Bu doğrultuda iyi oluş kavramı iki farklı alanda incelenmektedir. Bu alanlar, Psikolojik ve Öznel iyi oluş olarak ayrılmaktadır (Ryff, 1989). Psikolojik iyi oluşla ilişkili olan süreçler incelendiğinde; bireyin kendini gerçekleștirebilmesi ve mevcut potansiyelini en üst düzeyde kullanabilmesi ile bağdaştığı gözlemlenmektedir (Ryff, 1989). Bir başka tanıma göre psikolojik iyi oluş hali, bireyin yașamına dönük hedeflerinin farkında olması, ikili ilişkilerinde verimlilik ve bu ilişkilerin sürdürülebilmesi durumudur (Ryff ve Keyes, 1995). Öznel iyi oluşla ilișkili olan süreçler incelendiğinde ise bireylerin yaşamları hakkındaki günlük duyguları ile bu duyguların değerlendirilişi ile bağdaştığ gözlemlenmektedir. Bahsi geçen değerlendirmeleri, bireyler iki alanda gerçekleştirmektedir. $\mathrm{Bu}$ alanlar bilişsel ve duygusal olarak ayrılmaktadır. Bilişsel alanda yapılan değerlendirmeler yaşam doyumunu kapsamaktadır. Duygusal alanda yapilan değerlendirmeler ise pozitifnegatif duygu durumlarını kapsamaktadır (Kuyumcu ve Kabasakaloğlu, 2018).

TÜİK'in (2018) yaşam memnuniyeti araștırmalarına göre insanları en çok ailelerinin mutlu ettiği tespit edilmiştir. Kendisini en çok ailesinin mutlu ettiğini belirten bireylerin mutluluğuna etki eden diğer aile alt faktörleri incelendiğinde; \%12,9 ile çocuklar, \%3,6 ile eşleri, \%3,3 ile kendileri, \%2,7 ile ebeveynleri ve \%1,8 ile torunlarının geldiği gözlemlenmektedir. Bahsi geçen araştırmanın bulgularına göre bireylerin iyi oluş haline, aile ve çocukların etkisinin yüksek olacağını söylemek mümkünüdür.

İlgili alanyazın tarandığında kadınların psikolojik sağlığını ve bu sağlığa etki eden unsurlara yönelik çalıșmaların yapıldığı gözlemlenmektedir. Yapılan araştırmalar arasında Koyun ve diğerleri (2011) yaşam dönemlerine göre kadın sağlığını incelemiş ve doğurganlık döneminde kadın sağlığına değinerek gebelik ve doğumun kadındaki stres faktörlerini arttırdığ 1 ifade etmiştir. Uludağlı (2017) çocuk sahibi olmanın bireyi nasıl etkileyeceğini değerlendirmiş ve bu duruma ebeveyn açısından bakarak evlenmenin ve çocuk sahibi olmanın psikolojik sağllğı desteklediğini ifade etmiştir. Türkleş ve diğerleri (2013) evli ve çocuklu kadınlarda ruh sağlığının aile işlevine etkisi incelenmis ve ailedeki kiși sayısına paralel olarak kadınların ruhsal belirti düzeylerinde artma, aile işlevlerinde azalma olduğu tespit edilmiştir. Kayahan ve diğerleri (2003) doğurganlık döneminde kadınların depresyon durumunu kısmen de olsa çocuk sayısı altında incelemiş ve anlamlı bir farkın olmadığını tespit etmişlerdir. Sirin (2000) kadın sağlığına etki eden durumları incelemiş ve doğurganlığın artması ile sağlık arasındaki ters yönlü ilişkiyi düşük ve anne ölüm oranları ile tespit etmiștir. Eryılmaz ve Ercan (2011) psikolojik iyi oluşun ileri yaştaki kadınlarda daha yüksek olduğunu; Eroğlu ve Parlar (2018) evli kadınlarda pozitif duygu durumunun yüksek olması halinde çocuklara karşı uygulanan otoriter tutumların azalacağı ve izin verici tutumların artacağı yönünde sonuçlara ulaşılmıştır.

Bahsi geçen araştırmalar pozitif negatif duyguları, bu duygulara etki eden unsurların ve meydana gelebilecek zararlı sonuçların anlaşılmasına yardımcı olmuştur. Ancak ülkemizde özellikle kadınlarda çocuk sahibi olmanın ve cocuk sayısı ile pozitif negatif duygular arasındaki ilișkinin tespitine yönelik bir araștırmaya rastlanmamıştır. Dolayısıyla bu araştırmanın literatüre katk1 sağlayacağı gibi aile sağlığının korunması ve geliștirilmesinde izlenecek uygulamalara yol gösterici olmas1 hedeflenmektedir.Yapılan açıklamalar doğrultusunda kadınların pozitif ve negatif duygu durumumun da ailelerine ve cocuklarına bağlı olarak değişim göstermesi kabul edilebilir bir sonuç olmaktadır. Dolayısıyla araştırmanın temel amacı kadınlarda çocuk sayısı ile pozitif negatif duygu durumları arasındaki ilişkinin tespitidir.

\section{Yöntem}

Çalıșmanın bu bölümünde, araștırma amacı, evrenörneklemi, prosedürü, veri toplama araçları ve araştırma verilerinin değerlendirilmesine yer verilmiştir.

\section{Araștırmanın Örneklemi}

Türkiye Bağımlılık Risk Profili ve Ruh Sağlığı Haritası Projesi (TURBAHAR) örneklem tasarımı ve büyüklüğü, Türkiye geneli, dokuz demografik bölge (Akdeniz, Ege, Batı Karadeniz, Doğu Karadeniz, Doğu Anadolu, İç Anadolu, Batı Marmara, Doğu Marmara, İstanbul) için analiz yapmaya imkân vermektedir. TURBAHAR örneklem seçiminde tabakalı küme örneklemesi yaklaşımı kullanılmıștır. Örneklem, 26 NUTS3 bölgesindeki katılımcılar üzerinden planlanmıştır. Dokuz demografik bölgenin tamamında, en az 200 en çok 2000 kişi araștırmaya dâhil edilmiștir. Araștırma kapsamında olma kriteri olarak cinsiyet ve yaş baz alınmıştır. Dolayısıyla 18 yaşın üstünde, gönüllü ve anketlerin doldurulmasında herhangi bir engeli olmayanlar kabul edilmiștir. Bahsi geçen demografik bölgelerde nüfus yoğunluğuna paralel olarak örneklem seçilmiştir. Anket çalışması kapsamında 24990 kişiyle temasa geçilmiştir. $\mathrm{Bu}$ katılımcılar arasından, 24494 kișiye ait olan verilerin; ilgili kriterleri karşıladiğı ve ölçekleri tam olarak doldurduğu gözlemlenmiştir. TURBAHAR projesi kapsamında erkek ve kadın katılımcılardan olușan her yaștan bireye farklı anket ölçekleri yöneltilmiştir. Katılımcılar arasından makalenin araştırma konusu kapsamında olan ölçekleri 
yanıtlayan 12189 kadın katılımcının anketi araştırmaya dâhil edilmiştir.

\section{İşlem}

TURBAHAR'ın alan çalışmasında 125 klinik psikolog verilerin toplanmasında görev almıştır. Görevli her psikolog kendi lokasyonundaki kişilere ulaşarak veri toplamıştır. Klinik psikologlar dokuz alt bölge temsilcisiyle koordineli olarak faaliyetlerini sürdürmüştür. Dokuz alt bölge temsilcisi ise dört üst bölge temsilcisiyle koordineli olarak faaliyetlerini sürdürmüștür. Araștırma yönetimi iki öğretim üyesi tarafindan gerçekleştirilmiştir. $\mathrm{Bu}$ hiyerarșiye bağlı olarak tüm ekip bir üst bölge temsilcisine karş sorumlu olmustur. Dolayısıyla tüm görevliler öğretim üyelerine karşı sorumlu olarak faaliyetlerini sürdürmüştür.

Araştırma 07/2018-10/2018 tarihleri arasında gerçekleștirilmiștir. Araștırma katılımcıları okullar, belediyeler, özel şirketler gibi çeşitli çalışma alanları ve muhtarlık, ortak kamu alanları, kurslar, yardım dernekleri gibi kamu alanlarındaki bireylerden seçilmistir. Potansiyel katılımcılara araştırma süreçleri hakkında bilgi verilmesinden sonra araştırmanın amacı açıklanmış ve katılımda bulunmak isteyip istemedikleri sorulmustur. 18 yaş ve üzerinde olan bireyler çalışmaya dahil edilmiştir. Bilgilendirilmiş gönüllü formunun imzalanmasının ardından katılımcılara içerisinde veri toplama araçlarının bulunduğu, kitapçık haline getirilmiş anketler sunulmuştur. Gönüllüler anketleri bireysel olarak ancak araștırmacı gözetiminde doldurarak araştırmacıya geri teslim etmişlerdir. Ölçeklerle ilgili yönergeler hem sözel olarak ifade edilmiş hem de yazılı olarak verilmiştir. Anketlerin cevaplandırılması sürecinde yardım isteyen katılımcıların ilgili sorun ve soruları yanıtlanmıstır. Anketlerin içeriksel uzunluğu nedeni ile katılımcılara cevaplandırma için herhangi bir zaman sınırlaması getirilmemistir. Katılımcıların ortalama anket doldurma süresi 45 dakika olarak tespit edilmiştir. Cevaplandırma sürecinden sonra katılımcılara ilgili iletişim bilgileri verilmiștir. Calıșmanın Etik Kurulu Onayı Üsküdar Üniversitesi Girişimsel Olmayan Etik Kuruldan alınmıştır.

\section{Veri Toplama Araçlar}

Katılımcılar, dağıtılan kitapçığın ilk sayfasında, araștırmaya gönüllülük esasına göre katıldıklarını beyan ettikleri bir onam formu imzalamışlardır. Katılımcıların imzaladıkları onam formunda çalışma kısaca açıklanmış, amaca değinilmiș, katılımcıların ölçek ve anketleri cevaplamaları istenmiștir. Araștırmacıların hazırladığ 1 bu bölüm, katılımcıların; yaş, eğitim, medeni durum, cinsiyet, çocuk sayısı, çalışan sayısı, sigara, alkol, madde kullanım özellikleri, psikiyatri tedavisi bașuru öyküleri ve silah bulundurma sorularını içermektedir. Araştırmada veri toplama aracı olarak Pozitif ve Negatif Duygulanım Ölçeği (PNDO) kullanılmıștır. Watson, Clark ve Tellegen (1988) tarafından geliştirilen PNDO; 10'u pozitif, 10'u negatif alt faktöründen oluşan 20 maddelik bir ölçektir. Beşli likert tipinde hazırlanan ölçekte alınabilecek en yüksek puan 100'dür. Ölçek; belirli bir zamanda bir bireyin pozitif ve negatif duygu durumunu kendi kendine raporlamasına imkân sağlayan sorulardan oluşmaktadır. Pozitif alt boyutunun Cronbach alfa güvenilirlik katsayıs1 ,88, negatif alt boyunun Cronbach alfa güvenilirlik katsayısı ,85'tir. Ölçeğin Türkiye Geçerlilik ve Güvenilirlilik analizleri Gençöz (2000: 25) tarafından yapılmıştır.

\section{Verilerin Değerlendirilmesi}

Araştırma sonucunda elde edilen Sosyo-Demografik özellik ve beş farklı ölçek verileri SPSS (Statistical PackagefortheSocialSciences) paket program1 kullanılarak analiz edilmiştir. Katılımcılar, sahip olunan çocuk sayısı durumu cevaplarına göre " $0,1,2,3$ ve üzeri”" seklinde dört guruba ayrılmışlardır.Örneklem kadınlarda sahip olunan çocuk sayısı ile negatif-pozitif duygular arasında ve içindeki ilişkiye göre gruplara ayrılmıştır. Uç veya daha çok bağımsız ortalama arasındaki farkın analizi için Tek Yönlü Varyans Analizi (ANOVA) kullanılmıştır. Bulunan farkların hangi gruplar arasında olduğunu tespit etmek için de Tukey testi yapılmıştır.

\section{Bulgular}

$\mathrm{Bu}$ bölümde araștırmanın bulguları ve değerlendirmesine yer verilmektedir. Bu bağlamda demografik verilere dair tanımlayıcı istatistikler ve araştırmada kullanılan ölçeklerde çocuk sayısı düzeylerine göre anlamlı bir farkın olup olmadığının analiz sonuçları detaylı bir şekilde sunulmaktadır.

\section{Sosyo-Demografik Bulgular}

Çalışmalar sonucunda katılımcılar arasındaki 12191 kadının anketi analiz edilmiștir. Verilerin analize uygun olması açısından 12189 anket analize dâhil edilirken 2 anket kayıp veri nedeniyle analize dahil edilmemiştir. Katılımcılardan toplanan anketler ile elde edilen çocuk sahibi olma durumuna dair tanımlayıcı istatistikler Tablo 1 'de verilmiştir. Katılımcılar arasında \%60,4'lük (7364) oranla hiç çocuğu olmayanlar ağırlıklı kütleyi oluşturmaktır. Tek çocuğu olanların oranı \%14,6, iki çocuğu olanların oranı \%18,1 iken üç ve üzeri çocuk sahibi olanların oran $1 \% 6,9$ 'dur.

Calışmalar sonucunda toplanan anketlerin hepsi analize dâhil edilememiștir. Kadınlarda yaş gurubu ve çocuk sayısı arasındaki ilişkinin incelenmesinde; toplanan verilerin analize uygun olması açısından 12167 anket analize dâhil edilirken 22 anket kayıp veri nedeniyle analize dahil edilmemiştir. Katılımcılardan toplanan anketler ile elde edilen kadınlarda yaş gurubu ve çocuk sayıs1 durumuna dair tanımlayıcı istatistikler Tablo 2'de verilmiştir.

Katılımcıların yaş gruplarına göre çocuk sayısı grupları dağglımı incelendiğinde; 18-23 yaş grubunda bulunan 3472 kişinin 3393 kisisi çocuk sahibi değilken, 52 kiși bir çocuk, 22'si iki çocuk, 5'i üç ve daha fazla çocuğa sahiptir. 24-29 yaş grubunda bulunan 3223 kişinin 2692 kișisi çocuk sahibi değilken, 365 kiși bir çocuk, 133'ü iki çocuk, 33'ü üç ve üzeri çocuk sahibidir. 30-38 yaş grubunda bulunan 2597 kişinin 910 kişisi çocuk sahibi olmayıp, 791 kiși bir çocuk, 700'ü iki çocuk, 602'si üç ve üzeri çocuk sahibidir. 39 ve üzeri yaş gurubunda bulunan 2875 kişinin 355 kişisi çocuk sahibi değilken, 568 kişi bir çocuk, 1350'si iki çocuk, 602'si üç ve üzeri çocuk sahibi olduğu gözlemlenmiştir.

Kadınlarda eğitim düzeyi ve çocuk sayısı arasındaki ilişkinin incelenmesinde; toplanan verilerin analize uygun olması açısından 12181 anket analize dâhil edilirken 8 anket kayıp veri nedeniyle analize dahil edilmemiştir. Katılımcilardan toplanan anketler ile elde edilen kadınlarda eğitim düzeyi ve çocuk sayısı durumuna dair tanımlayıcı istatistikler Tablo 3'te verilmiștir.

Katılımcıların eğitim düzeyi ile çocuk sayı grubu arasındaki ilişski incelendiğinde; okuryazar olmayan 15 kișinin dördü çocuk sahibi olmayıp, biri bir çocuk, ikisi iki çocuk, sekizi üç ve daha fazla sayıda çocuk sahibidir. Okuryazar olan 133 kişinin 88'i hiç çocuk sahibi değilken, beși bir çocuk, 15 'i iki çocuk sahibi olup 25'i üç ve üzeri sayıda çocuk sahibidir. İlkokul mezunu olan 730 kişinin 72'si çocuk sahibi olmayıp, 77'si bir çocuk, 323'ü iki çocuk sahibi olup 258'i üç ve üzeri çocuk sahibidir. Ortaokul mezunu olan 614 kissinin 188'i hic çocuk sahibi olmayıp, 97'si bir çocuk, 189'u iki çocuk sahibi olup 140'1 üç ve üzeri çocuk sahibidir. Lise mezunu olan 2923 kisinin 1475'i hic cocuk sahibi olmayıp, 494'ü bir çocuk, 724'ü iki çocuk, 230'u ise üç ve üzeri sayıda çocuğa sahiptir. Üniversite mezunu olan 6853 kişinin 4901'i cocuk sahibi olmayıp, 944'ü bir çocuk, 846'sı iki cocuk, 162 'si ise üç ve üzeri sayıda çocuğa sahiptir. Yüksek lisans mezunu olan 913 kişinin 631'i çocuk sahibi olmayıp, 159'u bir çocuk, 109'u iki çocuk, 14'ü ise üç ve üzeri sayıda çocuğa sahip olduğu gözlemlenmiştir. 
Tablo 1. Katılımcıların Çocuk Sayısına Göre Dağılımı

\begin{tabular}{lll}
\hline Çocuk Sayısı & $\mathbf{N}$ & $\mathbf{\%}$ \\
\hline 0 Çocuk & 7364 & 60,4 \\
1 Çocuk & 1778 & 14,6 \\
2 Çocuk & 2210 & 18,1 \\
3 Çocuk & 837 & 6,9 \\
Toplam & 12189 & 100,0 \\
\hline
\end{tabular}

Tablo 2. Kadınlarda Yaş Grubu ve Çocuk Sayısı Arasındaki İlişkiye Ait Bulgular

\begin{tabular}{|c|c|c|c|c|c|c|}
\hline & & Çocu & & & & \\
\hline & & 0 & 1 & 2 & 3 & Toplam \\
\hline & $18-23$ & 3393 & 52 & 22 & 5 & 3472 \\
\hline Yas Grubu & $24-29$ & 2692 & 365 & 133 & 33 & 3223 \\
\hline Taş Grubu & $30-38$ & 910 & 791 & 700 & 196 & 2597 \\
\hline & 39 'den fazla & 355 & 568 & 1350 & 602 & 2875 \\
\hline Toplam & & 7350 & 1776 & 2205 & 836 & 12167 \\
\hline
\end{tabular}

Tablo 3.Kadınlarda Eğitim Düzeyi ve Çocuk Sayısı Arasındaki İlişkiye Ait Bulgular

\begin{tabular}{lllllll}
\hline & & \multicolumn{3}{l}{ Çocuk sayısı } & & \\
\cline { 3 - 5 } & & 0 & 1 & 2 & 3 & Toplam \\
& Okur Yazar/Değil & 92 & 6 & 17 & 33 & 148 \\
Ĕgitim Düzeyi & İkokul & 72 & 77 & 323 & 258 & 730 \\
& Ortaokul & 188 & 97 & 189 & 140 & 614 \\
& Lise & 1475 & 494 & 724 & 230 & 2923 \\
Toplam & Üniversite & 4901 & 944 & 846 & 162 & 6853 \\
& Yüksek Lisans & 631 & 159 & 109 & 14 & 913 \\
& & 7359 & 1777 & 2208 & 837 & 12181 \\
\hline
\end{tabular}

\section{Araştırma Ölçeklerinin Bulgular}

Araştırmaya katılan kadınların sahip oldukları çocuk sayıs1 ile Pozitif ve Negatif Duygu düzeylerinin ortalamaları arasında anlamlı bir fark olup olmadığı tek yönlü varyans analizi ile analiz edilmiş ve analiz sonuçları Tablo 4'te verilmiştir.

Analiz sonuçlarına görearaștırmaya katılan kadınların sahip oldukları çocuk sayısı ile Pozitif Negatif Duygu Ölçeği- Pozitif Duygu düzeylerinin ortalamaları arasında anlamlı bir farkın olduğu görülmüștür $(p<0,05)$. Farklılığın hangi gruptan kaynaklandığını tespit etmek için yapılan TUKEY testi sonuçlarına göre Pozitif Duygu alt boyutu için tek çocuk sahibi kișilerin ortalaması hiç çocuğu olmayan ve 3 ve daha fazla sayıda çocuğu olanlardan anlamlı derecede daha yüksektir. Ek olarak 2 çocuk sahibi kişilerin ortalaması hiç çocuğu olmayanların ortalamasından anlamlı derecede daha yüksektir.

Tablo 4'te görüldügüü üzere araștırmaya katılan kadınların sahip oldukları çocuk sayısı ile Pozitif Negatif Duygu Ölçeği- Negatif Duygu düzeylerinin ortalamaları arasında anlamlı bir farkın olduğu görülmüștür $(p<0,05)$. Farklılığın hangi gruptan kaynaklandığını tespit etmek için yapılan TUKEY testi sonuçlarına göre Negatif Duygu alt boyutu için hiç çocuğu olmayanların ortalaması diğer grupların hepsinden anlamlı derecede daha büyüktür.

Tablo 4: Katılımcıların “PNDOPD” Puanlarının Çocuk Sayısına Göre Anova Analizi

\begin{tabular}{|c|c|c|c|c|c|c|c|}
\hline & Değişken & $\mathbf{N}$ & Ortalama & $\mathbf{S}$ & $\mathbf{F}$ & $\mathbf{P}$ & Anlamlı Farklılık \\
\hline \multirow{5}{*}{$\begin{array}{l}\text { Pozitif } \\
\text { Duygu }\end{array}$} & 0 Çocuk Sahibi & 7349 & 29,63 & 7,92 & \multirow{5}{*}{12,486} & \multirow{5}{*}{, 000} & \\
\hline & 1 Çocuk Sahibi & 1775 & 30,77 & 7,76 & & & $1>0$ \\
\hline & 2 Çocuk Sahibi & 2200 & 30,32 & 7,63 & & & $1>3$ \\
\hline & 3 ve Üzeri Çocuk Sahibi & 836 & 29,7 & 7,95 & & & $2>0$ \\
\hline & Toplam & 12160 & 29,93 & 7,86 & & & \\
\hline \multirow{5}{*}{$\begin{array}{l}\text { Negatif } \\
\text { Duygu }\end{array}$} & 0 Çocuk Sahibi & 7349 & 20,19 & 7,04 & \multirow{5}{*}{77,04} & \multirow{5}{*}{, 000} & \\
\hline & 1 Çocuk Sahibi & 1775 & 18,27 & 6,58 & & & $0>1$ \\
\hline & 2 Çocuk Sahibi & 2200 & 18,12 & 6,33 & & & $0>2$ \\
\hline & 3 ve Üzeri Çocuk Sahibi & 836 & 18,79 & 6,43 & & & $0>3$ \\
\hline & Toplam & 12160 & 19,44 & 6,87 & & & \\
\hline
\end{tabular}

$* \mathrm{p}<0,05$

\section{Tartışma ve Sonuç}

Kadınlarda çocuk sayısı ile pozitif negatif duygular arasındaki ilişkinin tespitinin amaçlandığı bu çalışmada önemli sonuçlara ulaşılmıştır. İlgili amaç doğrultusunda elde edilen bulgularda; tek çocuğa sahip kadınların hiç çocuğa sahip olmayan ile üç ve üzeri çocuğa sahip olan kadınlara göre pozitif duygularda anlamlı farklılık göstermiştir. Ayrıca iki çocuğa sahip olan kadınlar hiç çocuk sahibi olmayan kadınlara göre pozitif duygularda anlamlı farklılık kaydetmiştir. Ancak tek çocuk sahibi olanlarda daha yüksek olarak tespit edilmiștir. $\mathrm{Bu}$ sonuçlara göre ilk çocuğuna sahip olan kadınların pozitif duyguları artarken çocuk sayısı arttıkça pozitif duygularında azalma olduğu söylenebilir. Negatif duygulardaki anlamlı farklılıklar incelendiğinde hic çocuğu olmayan kadınların diğer tüm gruplardan anlamlı derecede yüksek olduğu gözlemlenmektedir. $\mathrm{Bu}$ sonuçlara göre kadınlar çocuk sahibi olmasına bağlı olarak negatif duygularında azalma olduğu söylenebilir.
Ancak bir önceki ölçeği baz alarak çocuk sayısı arttıkça pozitif duygularında azaldığı şeklinde bir çan eğrisi oluştuğu söylenebilir

Bulgularda görüldüğü üzere çocuk sahibi olmanın negatif ve pozitif duygular üzerinde etkisi olduğu tespit edilmiştir. Alanyazın tarandığında doğrudan kadınlarda çocuk sayısı ve pozitif negatif duygu durumu arasındaki ilișki ile ilgili benzer çalıșmalara ulaşılamadığı için araştırmanın sonuçları çocuk sahibi olmanın pozitif negatif duygu durumu değişkenlerini etkilemesi ile alakalı olduğu kabul edilen çalışmalar çerçevesinde tartışılmıştır.

Literatürde çocuk sahibi olmanın kadınların pozitif duygularında olumlu yönde artışa neden olduğu tespit edilen çalışmalar bulunmaktadır. Bu çalışmalar arasında Uludağlı (2017) yapmıș olduğu nitel araştırmada evlenmenin ve çocuk sahibi olmanın bireylerin psikolojik sağlına olumlu katkısı olduğunu ifade 
etmiştir.Mcdonough ve arkadaşlarının (2002) Kanada'daki 25-64 yaş arası 6000 kadın katılımcı ile yapmış olduğu araştırmada çocuk sahibi olan kadınların cocuk sahibi olmayan kadınlara göre psikolojik sağlıklarının daha iyi olduğu sonucuna varılmıştır. Kendig ve arkadaşlarının (2007) Avusturalya, Finlandiya ve Hollandalı 2141 yaşlı kadın katılımcı üzerinde yaptığı araştırmada ebeveyn olmanın davranışları düzenlediği, çocuk sahibi olmayan kadınlara göre olumlu duyguları arttırdığı sonucuna varılmıştır.

Rimehaug ve Wallander'in (2010) Norvec HUNT2 toplum sağlığı çalışması kapsamında 30-49 yaş arası 24040 kadın katılımcı ile yapmış oldukları araştırmada çocuk sahibi olan kadınların olmayanlara göre anksiyete ve depresyon belirtilerinin daha düşük olduğu sonucuna ulaşılmıştır. Benzer sonuçları içeren çalışmalardan bir diğeri iseHelbig ve arkadaşlarının (2006) 18-49 yaş gurubu 2801 kadın katılımcı yaptıkları araştırmada çocuk sahibi olan kadınların depresif bozukluk oranlarının daha düşük olduğunu tespit etmişler ve bu sonuçlar araştırma bulguları ile örtüsmektedir.McQuillan ve arkadaslarının (2007) Amerika'da 25-50 yaş arası 580 orta batılı kadın katılımcı ile yapmış oldukları araştırmada ebeveyn olan kadınların olmayanlara göre yaşam doyumunun daha yüksek olduğu ve kısır olduğu öğrenilen kadınların yaşam doyumlarının çok daha düşük olduğu sonucuna ulaşılmıştır.

Benzer sonuçlara ulaşan bir diğer çalıșma iseKohler ve arkadaşlarının (2005) Danimarkalı ebeveynler üzerinde yaptığı incelemedir. Bu çalışmada çocuk sahibi olmanın yaşam doyumuna ve mutluluğa etkisi psikolojik iyi olus ile incelenmiş ve 25-70 yaş arası 3226 kadın katılımcıdan toplanan sonuçlarda ilk çocuğu olan kadınların diğer tüm kadın guruplarından daha yüksek yaşam doyumuna sahip olduğu tespit edilmiștir. Zhang ve Hayward'ın (2001) çocuksuzluğun, yaşlıların iyi oluşundaki etkileri üzerine yapmış oldukları araştırmada 70 yaş üstü 4081 kadın katılımcıdan elde edilen sonuçlarda çocuk sahibi olmamanın depresyonu arttırdığı yönünde kanıt bulunmazken yalnızlığı yüksek oranda arttırarak psikolojik iyi oluşu negatif yönde etkilediği tespit edilmiştir. Ancak Koyun ve arkadaşlarının (2011) yapmış olduğu nitel araştırmada gebelik ve doğum gibi durumların kadınların stres faktörlerini arttırarak sağlıklarını olumsuz anlamda etkilediği ifade edilmiștir. Ayrıca Çilli ve arkadaşlarının (2004) 144 kadın katılımcı ile yapmış olduğu çalışmada çalışan kadınlarda veya ev kadınlarındaçocuk sayısına bağlı olarak negatif duygu durumlarındabir etki olmadığını ifade etmişlerdir.

Sonuç olarak, aile, evlilik ve anne sağlığ kavramlarının kültürümüzdeki önemi temel alındığında kadınlarda çocuk sayısına bağlı olarak pozitif negatif duygu durumunun incelenmesi ilgili alana önemli bir katkı sağlamış olacaktır. Alanda benzer çalışmaların olmaması nedeniyle bu calıșmanın yapılacak yeni araștırmaların bulgularıyla desteklenmesi yarar sağlayacaktır. Ayrıca bu araştırmanın diğer araştırmalarda olduğu gibi bazı sınırlılıkları bulunmaktadır. Calıșmanın en önemli sınırlılığı annelerin sahip oldukları veya olamadıkları diğer sosyal statülerin çalışmaya dâhil edilememesidir. Kadınlardaki pozitif negatif duygu durumunun çocuk sayısına bağlı olarak incelendiği bu çalışmaya ek olarak anne mesleki ve çalışma durumu, evli/dul olma durumu ve zaman içerisinde bu durumların değișme durumuna bağlı olarak pozitif negatif duygu durumlarındaki değişimin irdelenmesi araştırmacılara tavsiye edilebilir. Bu tavsiyeye ek olarak yapılacak çalıșmalarda daha farklı nicel ve nitel araștırma tekniklerinin kullanılarak desteklenmesi ile alan yazına katkı sağlanabilir.

\section{Kaynaklar}

Attar, A. A. (2015). Doğurganlık kararları, akılcı seçim ve Türkiye'de nüfus politikası, Türkiye Dördüncü Nüfusbilim Konferansı, Hacettepe Üniversitesi, İstanbul, 1-19.

Aysan, M. F. (2015). Türkiye'de aile yapısındaki değișim ve doğurganlığın düşüşü, Türkiye Dördüncü Nüfusbilim Konferansl, Hacettepe Üniversitesi, İstanbul, 155-168.

BM-UNFPA. (2019). Birleşmiş Milletler nüfus fonu raporu, Https://Turkey.Unfpa.Org/Tr/Node/9687, Erişim Tarihi: 06,2019

Çilli, A. S., Kaya, N., Bodur, S., Özkan, İ. ve Kucur, R. (2004) Ev kadınlarında ve çalıșan evli kadınlarda psikolojik belirtilerin karşılaştırılması, Genel Tip Dergisi, 14 (1), 1-5.

Eroğlu, F. ve Parlar, H. (2018). Evli kadın ve erkeklerde psikolojik iyi oluşun ebeveyn tutumuna etkisinin incelenmesi, İstanbul Ticaret Üniversitesi Sosyal Bilimler Dergisi, Cilt: 17, Say1: 33

Eryılmaz, A. ve Ercan, L. (2011), Öznel iyi oluşun cinsiyet, yaş grupları ve kişilik özellikleri açısından incelenmesi, Türk Psikolojik Danışma ve Rehberlik Dergisi, 4 (36), 139-151

Helbig, S., Lampert, T., Klose, M. ve Jacobi, F. (2006). Is parenthood associated with mental health findings from an epidemiological community survey, Social Psychiatry and Psychiatric Epidemiology, 41(11), 889-896.

Http://www.Tuik.Gov.Tr/Prehaberbultenleri.Do?İd=27588 Erișim tarihi: Haziran 04, 2019

Http://Tuik.Gov.Tr/Prehaberbultenleri.Do;Jsessionid=2pd7 ckvw pccpy9x8yrxlpyvfdg173xhwf24zlddvr2qs1s1md9lt!1347718495 ? Id $=30702$. Erișim tarihi: Mayıs 05, 2019

Kayahan, B., Altıntoprak, E., Karabilgin, S. ve Öztürk, Ö (2003). On beş-kırk dokuz yaşları arasındaki kadınlarda depresyon prevalansı ve depresyon şiddeti ile risk faktörleri arasındaki iliski, Anatolian Journal Of Psychiatry, 4, 208-219

Kendig, H., Dykstra, P. A., Gaalen, R. I. ve Melkas, T. (2007). Health of aging parents and childless individuals, Journal of Family Issues, 28(11), 1457-1486.

Kılınç, A. S., Catak, B., Sütlü, S. ve Akın, A. (2012). Dünya'da ve Türkiye'de kadın sağlığının durumu, Sağllk ve Toplum Dergisi, 22(2), 3-10.

Kohler, H., Behrman, J. R., ve Skytthe, A. (2005). Partner + Children = happiness: theeffects of partner ship and well-being, Population and Development Review, 31, 407-443
Koyun, A., Taşkın, L. ve Terzioğlu, F. (2011). Yaşam dönemlerine göre kadın sağlı̆̆ ve ruhsal ișlevler: hemșirelik yaklaşımlarının değerlendirilmesi, Psikiyatride Güncel Yaklaşımlar Dergisi, 3 (1): 67-99.

Kuğu, N. ve Akyüz, G. (2001). Gebelikte ruhsal durum, Cumhuriyet Üniversitesi Tip Fakültesi Dergisi, 23 (1): 61-64.

Kuyumcu, B. ve Kabasakaloğlu, A. (2018). Otantik olmanın duyuşsal iyi oluşu (pozitif-negatif duygu durumu) yordama gücü: Türk ve İngiliz üniversite öğrencileri arasında otantik olma ve pozitif-negatif duygu durumu, Yükseköğretim ve Bilim Dergisi, 8(1), 184-193

McDonough, P., Walters, V. ve Strohschein, L. (2002). Chronic stress and the social patterning of women's health in Canada, Social Science \& Medicine, 54(5), 767-782.

McGregor, I.andLittle, B. R. (1998). Personal projects, happiness, and meaning: on doing well and being yourself, Journal Of Personality and Social Psychology, 74(2), 494

McQuillan, J., Torres Stone, R. A., \& Greil, A. L. (2007). Infertility and life satisfaction among women, Journal of Family Issues, 28(7), 955-981.

Rimehaug, T. \& Wallander, J. (2010). Anxiety and depressive symptoms related to parenthood in a large Norwegian community sample: the HUNT2 study, Social Psychiatry and Psychiatric Epidemiology, 45(7), 713-721.

Ryan, R. M. \& Deci, E. L. (2001). On happiness an human potentials: a review of research on hedonic and eudaimonic wellbeing, Annual Review of Psychology, 52, 141-166.

Ryff, C. D. (1989). Happiness is everyting, or is it? explorations on the meaning of psychological well-being, Journal of Personality and Social Psychology, 57(6), 1069-1081.

Ryff, C. D. \& Keyes, C. L. M. (1995). The structure of psychological well-being revisited, Journel of Personality and Social Pyschology, 69, 719-727.

Sarkkaya, E. (2019). Anne ruh sağlığı ve peripartum depresyon calıștayı, Türkiye Anne, Cocuk ve Ergen Sağliğl Enstitüsü, İstanbul

Şirin, A. (2000). Ülkemizdeki kadınların sosyo-demografik özellikleri, Ege Üniversitesi, Hemşirelik Yüksek Okulu Dergisi 16 (1): $73-89$ 
Türkleş, S., Yılmaz, M., Ozcan, A., Oncü, E. ve Karataş, B.

(2013). Kadınlarda ruh sağlığını ve aile ișlevlerini etkileyen etmenler, Anadolu Hemsirirelik ve Sağllk Bilimleri Dergisi, 16(3), $154-162$.
Uludağlı, N, P, (2017). Psikolojik sağlık açısından yetişkin olmak, Psikiyatride Güncel Yaklașımlar Dergisi, 9 (3), 263-283.

Zhang, Z. \& Hayward, M.D. (2001). Childlessness and the psychological well-being of older persons, Journal of Gerontology, Soc Sci, 56, 311-320. 